RELATEDNESS OF VIRION AND INTRACELLULAR PROTEINS OF THE MURINE CORONAVIRUSES JHM AND A59

Clifford W. Bond, Kevin Anderson, Susan Goss, and Lisa Sardinia

Department of Microbiology

Montana State University

Bozeman, MT. 59717

\title{
INTRODUCTION
}

Coronaviruses are a group of RNA viruses with positive polarity that cause a wide variety of diseases in many species including man. The structural proteins of coronaviruses have been studied extensively (reviewed in Robb and Bond, 1979). However, little attention has been focused on the intracellular proteins (Bond et al. 1979, Anderson et al. 1979, Siddel et al. 1980).

We have described 9 intracellular and viral-specific proteins of the murine coronaviruses JHM and A59 (Bond et al. 1979). Four of these 9 viral-specific proteins were identified as structural proteins.

In this communication, we compare the virion and intracellular viral-specific proteins of JHM and A59 viruses and describe posttranslational events observed in murine coronaviral-specific protein synthesis.

MATERIALS AND METHODS

Cells

The source and growth of the murine cell lines $17 \mathrm{CL}-1$ and DBT have been described previously (Sturman and Takemoto, 1972; Hirano et al. 1974; Bond et al. 1979). 
$\underline{\text { Virus }}$

The source and growth of the A59 and JHM virus stocks have been described previously (Bond et al. 1979). Cells were infected in suspension, and virus was adsorbed at $37^{\circ}$ for $30 \mathrm{~min}$ at a cell density of $10^{7} \mathrm{cell} / \mathrm{s} / \mathrm{ml}$. Adsorbed cells were centrifuged, resuspended in prewarmed $\left(37^{\circ}\right)$ Dulbecco's Modified Eagle's Medium with $2 \%$ fetal bovine serum (DME2) at a density of $2 \times 10^{6} \mathrm{cell} / \mathrm{s} / \mathrm{ml}$, plated into plastic culture dishes at a density of $3 \times 10^{5} \mathrm{cells} / \mathrm{cm}^{2}$, and reincubated at $37^{\circ}$.

\section{Preparation of Intracellular Proteins}

Cells were infected by JHM or A59 virus at a multiplicity of infection (MOI) of 0.3 plaque forming units (PFU)/cell, and incubated at $37^{\circ}$. At the labeling time indicated in the experiment, the cell layers were washed twice with methionine-free DME2, and pulselabeled with ${ }^{35} \mathrm{~S}$-methionine $(100 \mu \mathrm{Ci} / \mathrm{ml})$ in methionine-free DME 2 for the time period indicated. At the end of the pulse-period, the cell layers were washed twice with serum-free complete medium (DMEO), and chased with DME2 or lysed in situ. Cells were lysed in situ at $0^{\circ}$ with buffer B10 [10 mM Tris- $\overline{-H C}(\mathrm{pH} 7.4), 5 \mathrm{mM} \mathrm{MgCl}, \overline{0.5} \%$ (vol/vol) NP40, 0.1\% (wt/vol) sodium dodecyl sulfate (SDS), 1\% (vol/vol) Aprotinin, $50 \mu \mathrm{g} / \mathrm{ml}$ ribonuclease, $50 \mu \mathrm{g} / \mathrm{ml}$ deoxyribonuclease] and the cytoplasmic lysates were stored at $-20^{\circ}$.

\section{Immunoprecipitation}

Cytoplasmic lysates were immunoprecipitated as follows. A cytoplasmic lysate representing $1.25 \times 10^{6}$ cells $(50 \mu l)$ was diluted 10 fold with buffer Bll [50 mM Tris-HCl (pH 7.4), $150 \mathrm{mM} \mathrm{NaCl}$, $5 \mathrm{mM}$ EDTA, $0.02 \%$ (wt/vol) sodium azide, $0.05 \%$ (vol/vol) NP40, $1 \%$ (vol/vol) Aprotinin, 0.1\% (wt/vol) bovine serum albumin]. Twenty $\mu l$ of antisera (either mouse-anti-JHM virus or mouse-anti-A59 virus) were added to the suspension, incubated for one $\mathrm{hr}$ at $0^{\circ}$, and the immune complexes were precipitated with $50 \mu \mathrm{l}$ of $10 \%$ (vol/vol) fixed Staphylococcus aureus (Cowan) by incubation for one hr at $0^{\circ}$. Antiviral antisera were prepared as previously described (Robb and Bond, 1979), and fixed S. aureus (Cowan) were prepared as described by Kessler (1975). The pellets were washed 3 times with buffer Bll, and resuspended in $20 \mu \mathrm{l}$ of $20 \mathrm{mM}$ DTT, 1\% (wt/vol) SDS. The proteins were eluted and reduced by incubation at room temperature for $15 \mathrm{~min}$ followed by heating at $60^{\circ}$ for $5 \mathrm{~min}$. The $\mathrm{s}$. aureus (Cowan) were removed by centrifugation and the supernatant fraction was alkylated with $\mathrm{N}$-ethylmaleimide at $0^{\circ}$ for one $\mathrm{hr}$ as described by Crawford and 0'Farrell (1979). 


\section{Preparation of Virion Proteins}

Cells were infected by JHM virus or A59 virus at an MOI of 0.1 $\mathrm{PFU} / \mathrm{cell}$ as described above and incubated at $33^{\circ}$. At $10 \mathrm{hrs} \mathrm{PI}$, the infected cells were washed twice with methionine/5 DME2, and labeled with ${ }^{35} \mathrm{~S}$-methionine $(50 \mu \mathrm{Ci} / \mathrm{ml})$ in methionine/5 DME2. The cell culture fluid was harvested at $70 \%$ cell lysis (24-30 hrs PI) and centrifuged at $2000 \times \mathrm{g}$ for $20 \mathrm{~min}$. The supernatant fraction was layered onto a step gradient consisting of layers of $10 \%, 17 \%$, and $40 \%$ (wt/wt) potassium tartrate in PNE buffer [30 mM PIPES $(\mathrm{pH} 6.5), 100 \mathrm{mM} \mathrm{NaCl}, 1 \mathrm{mM}$ EDTA], and centrifuged at $153,400 \times \mathrm{g}$ for $90 \mathrm{~min}$ at $4^{\circ}$. The fraction containing infectious virus was diluted with PNE buffer, layered onto a linear gradient consisting of 10 to $40 \%$ (wt/wt) potassium tartrate in PNE buffer, and centrifuged to equilibrium at $208,800 \times \mathrm{g}$ for $5 \mathrm{hrs}$ at $4^{\circ}$. Fractions were pooled on the basis of radioactivity, and Aprotinin was added to $1 \%$ (vol/vol). The suspension was dialyzed against $0.01 \mathrm{M} \mathrm{NH}_{4} \mathrm{HCO}_{3}$, lyophilized, and the resulting powder was resuspended in buffer $B 10$. The suspension was adjusted to $20 \mathrm{mM}$ DTT, 1\% (wt/vol) SDS, and heated to $45^{\circ}$ for $5 \mathrm{~min}$. The proteins were alkylated with $\mathrm{N}$-ethylmaleimide for one $\mathrm{hr}$ at $0^{\circ}$ as described by Crawford and $0^{\prime}$ Farrell (1979).

\section{Polyacrylamide Slab Gel Electrophoresis}

Reduced and alkylated proteins were electrophoresed on $6 \%, 8 \%$, or $10 \%$ polyacrylamide slab gels as described by Laemmli and Favre (1973) with the following exception. The resolving gel was supplemented with $0.5 \%$ (wt/vol) linear polyacrylamide. Volumes representing approximately equivalent cell numbers were loaded in each lane of the slab gel.

\section{RESULTS}

Cells $(17 \mathrm{CL}-1)$ were infected with $A 59$ virus or mock infected and labeled with ${ }^{35} \mathrm{~S}$-methionine for $30 \mathrm{~min}, 60 \mathrm{~min}, 120 \mathrm{~min}$ or 180 min beginning at 8 hrs PI (Figure 1). This time point was chosen because it was a time of maximum protein synthesis, and was during the time of logarithmic production of infectious virus at $37^{\circ}$. The density of the major viral-specific protein bands $(150 \mathrm{~K}, 60 \mathrm{~K}$, 57K, $54 \mathrm{~K}$, and $23 \mathrm{~K}$ ) was a function of the length of the labeling time. The $22 \mathrm{~K}$ protein was not detectable until the length of the labeling period was $120 \mathrm{~min}$. The $22 \mathrm{~K}$ protein was readily detectable in a 180 min labeling period. An identical experiment was done with JHM virus, and similar data was obtained (data not shown). These data suggest that the $22 \mathrm{~K}$ protein may be the result of posttranslational modification of a precursor protein. To test this hypothesis, the following experiment was done. 
Cells $(17 \mathrm{CL}-1)$ infected with $A 59$ virus or mock infected were pulse-labeled with ${ }^{35} \mathrm{~s}$-methionine for $30 \mathrm{~min}$, and chased for $0 \mathrm{~min}$, $20 \mathrm{~min}, 40 \mathrm{~min}, 60 \mathrm{~min}, 80 \mathrm{~min}$, and $100 \mathrm{~min}$. Immunoprecipitates were electrophoresed on either $10 \%$ (Figure 2) or $6 \%$ (Figure 3) polyacrylamide slab gels. The results clearly indicate that the $23 \mathrm{~K}$ protein band lost density, and the $22 \mathrm{~K}$ protein band gained density during the chase (Figure 2). The density of the 150K band decreased during the chase (Figure 3). However, there was no concomitant increase of a corresponding protein during the chase. There was no significant evidence of posttranslational cleavage of precursor proteins in any other region of the gels. An identical experiment was done with JHM virus and similar data were obtained. Identical experiments were done using DBT cells infected by JHM virus or A59 virus, and similar results were obtained.

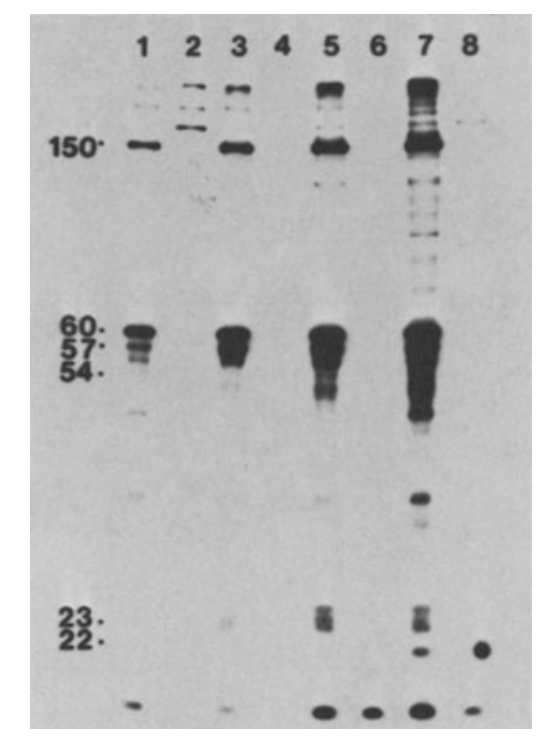

Fig. 1. The spectrum of viral-specific proteins synthesized by $17 \mathrm{CL}-1$ cells infected by $A 59$ virus or mock infected as a function of the length of the labeling period. Cells were infected with $A 59$ virus (lanes $1,3,5,7$ ) or mock infected (lanes $2,4,6,8)$, labeled with ${ }^{35} \mathrm{~S}$-methionine for $30 \mathrm{~min}$ (lanes 1, 2), 60 min (lanes 3, 4), $120 \mathrm{~min}($ lanes 5, 6) or $180 \mathrm{~min}(1 \mathrm{anes} 7,8)$, and immunoprecipitated. The immunoprecipitates were reduced and alkylated, and electrophoresed on an $8 \%$ polyacrylamide slab gel as described in Materials and Methods. 
Structural proteins of purified JHM and A59 virions were compared with the intracellular proteins described in the previous experiments. The results are shown in Figure 4. The $63 \mathrm{~K}$ intracellular protein of JHM virus and the $60 \mathrm{~K}$ protein of A59 virus comigrate with the respective structural proteins of purified virions. The $150 \mathrm{~K}$ and $22 \mathrm{~K}$ proteins are not evident in the virion lanes of Figure 4. However, both were faintly evident in the original autoradiograms suggesting that these proteins are precursors to the slower migrating species. The $23 \mathrm{~K}$ intracellular protein of JHM virus migrated slightly differently in comparison with the structural proteins of JHM virions. The 23K intracellular protein of A59 virus migrated slightly faster than the structural proteins of A59 virions. These data suggest that the $23 \mathrm{~K}$ protein is not directly assembled into the virion without modification.

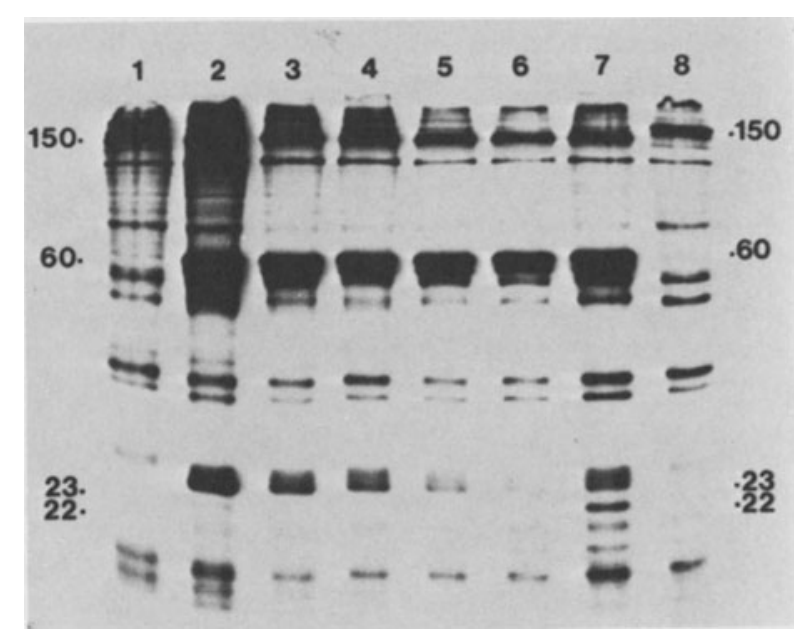

Fig. 2. Pulse-chase of viral-specific proteins synthesized by $17 \mathrm{CL}-1$ cells infected by $A 59$ virus or mock-infected. Cells infected by $A 59$ virus (lanes 2-7) or mock infected (lanes 1,8) were pulse-labeled with ${ }^{35} \mathrm{~S}$-methionine for $30 \mathrm{~min}$, chased for $0 \mathrm{~min}($ lanes 1, 2), $20 \mathrm{~min}$ (lane 3), $40 \mathrm{~min}$ (lane 4), $60 \mathrm{~min}$ (lane 5), $80 \mathrm{~min}$ (lane 6) or $100 \mathrm{~min}$ (lanes 7,8 ), and immunoprecipitated. The immunoprecipitates were reduced and alkylated, and electrophoresed on a $10 \%$ polyacrylamide slab gel as described in Materials and Methods. 


\section{DISCUSSION}

The data presented above demonstrate that the $23 \mathrm{~K}$ intracellular protein of JHM and $A 59$ viruses is processed to a $22 \mathrm{~K}$ protein which is assembled into the virion. The $23 \mathrm{~K}$ intracellular protein does not appear to be assembled directly into the virions of JHM and A59 without processing to the $22 \mathrm{~K}$ species because it migrates differently than the structural proteins of these viruses. The $61 \mathrm{~K}$ and $56 \mathrm{~K}$ intracellular proteins of JHM virus, and the $57 \mathrm{~K}$ and $54 \mathrm{~K}$ intracellular proteins of $A 59$ virus are not represented in the respective virions. Anderson et al. (1979) suggested that these proteins are the result of posttranslational modification of the $63 \mathrm{~K}$ protein (JHM) or the 60K protein (A59). The data shown in Figures 2 and 3 do not support this contention.

The 150K intracellular protein bands of JHM and A59 viruses decrease in density during the chase (Figure 3). We have previously shown that this protein is glycosylated by glucosamine and mannose (Bond et al. 1979). This protein is incorporated into the virion

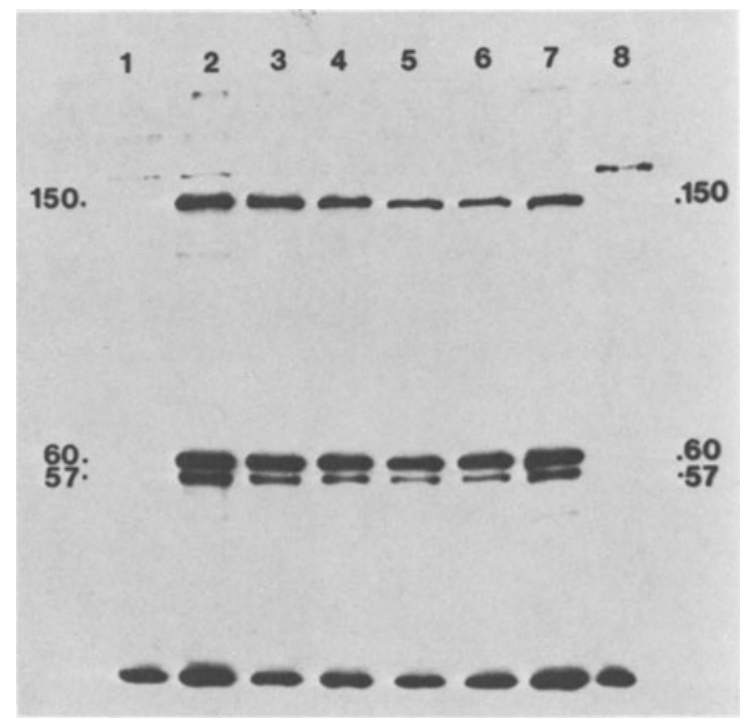

Fig. 3. Pulse-chase of viral-specific proteins synthesized by $17 \mathrm{CL}-1$ cells infected by $A 59$ virus or mock infected. The reduced and alkylated immunoprecipitates described in the legend to Figure 2 were electrophoresed in the corresponding lanes of a $6 \%$ polyacrylamide slab gel as described in Materials and Methods. 


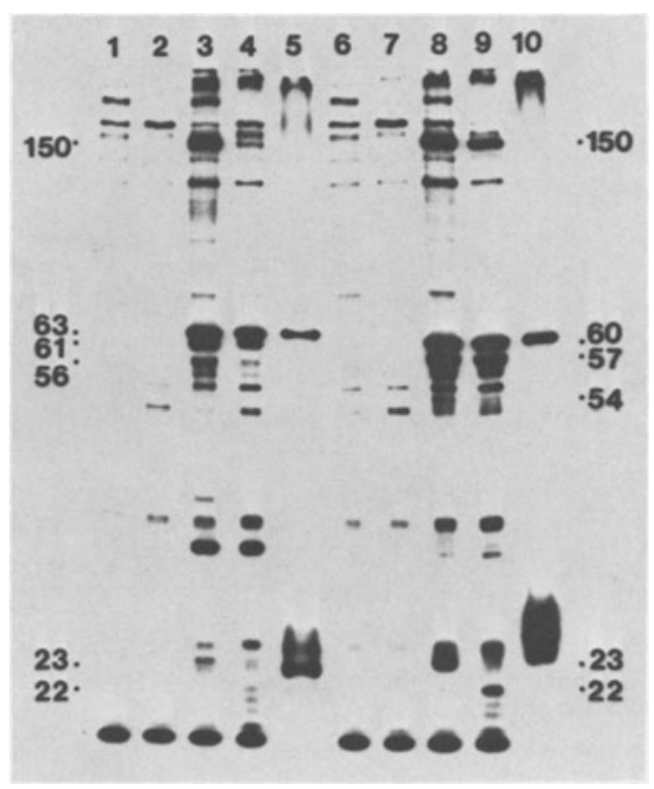

Fig. 4. Comparison of the intracellular and virion proteins of JHM virus and $A 59$ virus. Cells were infected by JHM virus (lanes 3, 4), A59 virus (lanes 8,9 ) or mock infected (lanes $1,2,6,7$ ), pulse-labeled with ${ }^{35}$ s-methionine for $30 \mathrm{~min}$, chased for 0 min (lanes $i, 3,6,8)$ or chased for $100 \mathrm{~min}$ (lanes 2, 4, 7, 9), and immuroprecipitated. Virion proteins of JHM (lane 5), and A59 (lane 10) were prepared as described in Materials and Methods. The immunoprecipitates and virion proteins were reduced and alkylated, and electrophoresed on an $8 \%$ polyacrylamide slab gel as described in Materials and Methods.

directly (Figure 4), and is probably then glycosylated to the slower migrating species found in the virion.

The pulse-chase experiments were done using DBT cells as well as $17 \mathrm{CL}-1$ cells. Similar results were obtained. These results indicate that the posttranslational modifications are viral-specific, and not cellular artifacts. Aprotinin, a protease inhibitor, was utilized throughout the processing steps to eliminate protease activity that would result in cleavage artifacts.

Further work including tryptic peptide mapping of the structural and intracellular viral-specific proteins is in progress to further define the relatedness of the intracellular and virion proteins of the murine coronaviruses JHM and A59. 


\section{REFERENCES}

Anderson, R., Cheley, S., and Haworth-Hatherell, E., 1979, Comparison of polypeptides of two strains of murine hepatitis virus, Virology, 97:492-494.

Bond, C.W., Leibowitz, J. L., and Robb, J. A., 1979, Pathogenic murine coronaviruses. II. Characterization of virus-specific proteins of murine coronaviruses JHMV and A59V, Virology, 94: $371-384$.

Crawford, L. V. and O'Farrell, P. Z., 1979, Effect of alkylation on the physical properties of simian virus 40 T-antigen species, J. Virol., 29:587-596.

Hirano, N., Fujiwara, K., Hine, S., and Matumoto, M., 1974, Replication and plaque formation of mouse hepatitis virus (MHV-2) in mouse cell line DBT culture, Arch. ges. Virusforsch., 44: 298-302.

Kessler, S. W., 1975, Rapid isolation of antigens from cells with a Staphylococcal protein A-antibody adsorbent: Parameters of the interaction of antibody-antigen complexes with protein A. J. Immunol., 115:1617-1624.

Laemmli, U. K. and Favre, M., 1973, Maturation of the head of bacteriophage T4: I. DNA packaging events, J. Mol. Biol., 80:575599.

Robb, J. A. and Bond, C. W., 1979a, Coronaviridae, in "Comprehensive Virology", vol. 14, H. Fraenkel-Conrat and R. R. Wagner, eds., pp. 193-247, Plenum Publishing Corp., New York.

Robb, J. A. and Bond, C. W., 1979b, Pathogenic murine coronaviruses. 1. Characterization of biological behavior in vitro and virus specific intracellular RNA of strongly neurotropic JHMV and weakly neurotropic A59V viruses, Virology, 94:352-370.

Siddell, S. G., Wege, H., Barthel, A., and Ter Meulen, V., 1980, Coronavirus JHM: Cell-free synthesis of structural protein p60, J. Virol., 33:10-17.

Sturman, L. S. and Takemoto, K., 1972, Enhanced growth of a murine coronavirus in transformed mouse cells, Infection and Immunity, $6: 501-507$. 